\title{
Analytical Network Process in Selection of 7PL
}

\section{J. Praveena, M. Pramila Devi}

\begin{abstract}
This article aims in selection and evaluation of a Seventh Party Logistic provider (7PL) which integrates all the functions of a company globally. The procedure for selection is based on the criteria's and their relative priority weights. Analytical Network Process (ANP) is used in complex problems where Multi-criteria decision making is involved. After identification of criteria using ANP final selection is done. This paper is informatory to researchers to understand and apply ANP to MCDM problems.
\end{abstract}

keyword- Analytical Network Process, Seventh party logistics, priority weight, criteria selection.

\section{INTRODUCTION}

Logistics is one of the complex problems which any industries find difficult to manage and maintain. With increasing global markets supply chain management faces many challenges.

The decision making is one of the important aspect for implementing logistics. Logistics outsourcing is growing trend now-a days. Decision makers faces many challenges in real time situations of selection for a given problem.

When it comes to scientific process of decision making can be represented as:

1. Identification of the problem.

2. Collection of quantitative data.

3. Analysis of data using scientific methods.

4. Structuring the alternatives which will suite the objective and result in solution to the problem.

Based on the business variety of services are needed, for which service providers are being used.

The services which mainly involve business-relation-ships, where clients and organization come together in such of logistics service provider [6]. Therefore, the client must identify exactly what are the needs from the provider. In management of logistics, criteria for the selection of a service provider is an important issue. However, the selection of a service provider, which satisfies requirement, should be identified. The complexity of identifying suitable service provider increases with the number of selection criteria been used.[9]

\section{ANALYTICAL NETWORK PROCESS (ANP)}

AHP and ANP are two methods to apply on MCDMmodel.AHP modeling helps to solve a hierarchy while ANP can be used for complex problems which cannot be modeled using hierarchy process.

Revised Manuscript Received on March 16, 2020.

*correspondence Author:

J.Praveena*, Department of Mechanical Engineering, Andhra University, Visakhapatnam, Andhra Pradesh, India. Email: jannavarapu.veena@gmail.com.

Prof.M.Pramila Devi, Department of Mechanical Engineering, Andhra University, Visakhapatnam, Andhra Pradesh, India. Email: pramiladevi_m@yahoo.co.in

(C) The Authors. Published by Blue Eyes Intelligence Engineering and Sciences Publication (BEIESP). This is an open access article under the CC BY-NC-ND license (http://creativecommons.org/licenses/by-nc-nd/4.0/)
Analytical Network Process modeling is used in MCMD. In Analytical Network Process, a network structure is used to represent decision comprising of different elements at each level. In a network, elements arrangement is not in any particular order, but are connected as pairs. The pairs wise comparisons of elements are paired according to the dominance between the member of an element. Many real world decision problems can be constructed using interdependencies.ANP is more objective and captures things that does not come to mind. Putting two observations together, ANP gives strong and effective decision making than AHP.

\section{METHODOLOGY}

The present method allows in evaluation of the providers in two stages i) Selection of criteria's and ii) an ANP-based modeling for selecting the 7PL service provider.

-Define objectives and services.

The objectives of service provider should be clearly defined. It should understand goals and sub-goals of the service provider to meet present and future needed of the company. -Identify the provider useful

To identify the provider useful for the service, proper survey should be conducted. Then the user company should check and implement future operations. -- -

-To generate information from data

Once identifying the service provider and send to request for information, then data of the providers on the basis of information given by organizations and their readiness to take part in logistics operations with outsourcing. The user should evaluate the response keeping in mind based on logistic needs when there are two or more logistic provider. -selection of best provider and its services as per agreements

Selection of the best provider is considered in this phase. Based on the evaluation and selection, all the weighted values are carried into matrices. Thus super matrix with weighted values is converted into convergent with final values, after rising to a sufficient power $2^{\mathrm{k}+1}$.

\section{RESULTS}

The super matrix is generated from local matrix which shows the priority weights. The priority weights of the companies obtained from ANP modeling. The super matrix, which when rise to a sufficient power convergence, as a result of which company A with highest weights has to chosen as best.

The major advantage of this paper is that it operates on different issues in selection of 7PL using Analytical Network process.

Further shows that the inter-dependencies among various parameters can be effectively captured after applying ANP technique, which helps in context of outsourcing decisions.

Blue Eyes Intelligence Engineering \& Sciences Publication 


\section{Analytical Network Process in Selection of 7PL}

\section{CONCLUSIONS}

This type of model can be applied to several sensitive analysis to evaluation the existing logistics process and to improve model with different fields that would develop better systems which can help the decision makers. Therefore, a significant model which is intelligent and user friendly can be designed on the basis of this model

\section{REFERENCES}

1. Foroughi, A., Rasoulian, M. and Esfahani, M. J. (2012), Prioritize strategies of university by using SWOT analysis and ANP method, American Journal of Scientific Research, No: 46, pp. 83-91

2. Lee S, Seo K-K. A multi-criteria decision-making model for an IaaS provider selection problem. International Journal of Advancements in Computing Technology. 2013; 12(5):363-7.

3. Meade, L. and Sarkis, J. Strategic analysis of logistics and supply chain management systems using the analytical network process, Transpn Res.- E (Logistics and Transpn Rev.) 34 (3),201\{215, 1998\}

4. Saaty, T. L. The Analytic Hierarchy Process, (RWS Publications, Pittsburg, PA, 1990).

5. Saaty, T. L. Decision Making with Feedback: The Analytical Network Process, (RWS Publications, Pittsburg, PA, 1996).

6. Saaty, T. L. Fundamentals of the Analytic NetworShyur, H. J., 2006, "COTS evaluation using TOPSIS and ANP," Applied Mathematics and Computation, Vol. 177, No. 1, pp. 251-259. 20.

7. Sarkis and Surrandaj Logistics strategy and structure-a conceptual framework. International Journal of Operations and Production Management 1998;18(1):37-52.

8. Super Decision Software for Decision Making, http://www.superdecisions.com. 21. Tan, K. C., 2001, “A framework of supply chain management literature," European Journal of Purchasing \& Supply Management, Vol. 7, No. 1, pp. 39-48. 22.

9. Tsai, M. C., Wen, C. H. and Chen, C. S., 2007, "Demand choices of high-tech industry for logistics service providers-an case of an offshore science park in Taiwan," Industrial Marketing Management, Vol. 36, No. 5, pp. 617-626. k Process, ISAHP 1999, (Kobe, Japan,August 1214, 1999)

10. Azis IJ. Analytic network process with feedback influence: a new approach to impact study. Prepared for a seminar organized by the Department of Urban and Regional Planning. Urbana-Champaign, University of Illinois; 2013

\section{AUTHOR PROFILE}

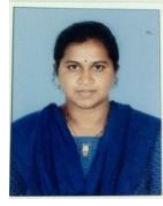

J.Praveena, working as Assistant Professor on contract in Department of Mechanical Engineering at Andhra University College of Engineering for Women, Visakhapatnam, Andhra pradesh , India. Currently pursuing Ph.d in the department of mechanical engineering , Andhra university,Visakhapatnam.Having a teaching experience of 11 years.

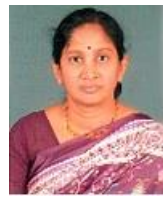

Prof. M. Pramila Devi, she is currently working as professor in the mechanical engineering department,Andhra university,Visakhapatnam, Andhra Pradesh, India.

APPENDIX

Table: 1 Goals C.I $=\mathbf{0 . 1 7 8 2 7}$

\begin{tabular}{|c|c|c|c|c|c|c|c|c|c|}
\hline Goal & $\begin{array}{c}\text { Man } \\
\mathrm{u}\end{array}$ & $\begin{array}{c}\text { IS } \\
\mathrm{C}\end{array}$ & $\begin{array}{c}\mathrm{QM} \\
\mathrm{T}\end{array}$ & $\begin{array}{c}\mathrm{ES} \\
\mathrm{C}\end{array}$ & $\begin{array}{c}\mathrm{SD} \\
\mathrm{M}\end{array}$ & $\mathrm{IC}$ & $\begin{array}{c}\mathrm{IT} \\
\mathrm{S}\end{array}$ & $\begin{array}{c}\mathrm{V} \\
\mathrm{L}\end{array}$ & Priority \\
\hline $\begin{array}{c}\text { Man } \\
\mathrm{u}\end{array}$ & 1 & 3 & 4 & 5 & 7 & 6 & 8 & 8 & 0.35967 \\
\hline ISC & $1 / 3$ & 1 & 2 & 3 & 5 & 6 & 7 & 9 & 0.21326 \\
\hline $\begin{array}{c}\text { QM } \\
\mathrm{T}\end{array}$ & $1 / 4$ & $1 / 2$ & 1 & 4 & 3 & 2 & 5 & 7 & 0.14845 \\
\hline ESC & $1 / 5$ & $1 / 3$ & $1 / 4$ & 1 & 5 & 4 & 2 & 6 & 0.10999 \\
\hline $\begin{array}{c}\text { SD } \\
\text { M }\end{array}$ & $1 / 7$ & $1 / 5$ & $1 / 3$ & $1 / 5$ & 1 & 4 & 6 & 8 & 0.07883 \\
\hline IC & $1 / 6$ & $1 / 6$ & $1 / 2$ & $1 / 4$ & $1 / 4$ & 1 & 2 & 5 & 0.04353 \\
\hline ITS & $1 / 8$ & $1 / 7$ & $1 / 5$ & $1 / 2$ & $1 / 6$ & $1 / 2$ & 1 & 3 & 0.02967 \\
\end{tabular}

\begin{tabular}{|c|c|c|c|c|c|c|c|c|c|}
\hline $\mathrm{VL}$ & $1 / 8$ & $1 / 9$ & $1 / 7$ & $1 / 6$ & $1 / 8$ & $\begin{array}{c}1 / \\
5\end{array}$ & & 1 & 0.01656 \\
\hline
\end{tabular}

Table:.2 Goal-1 C.I = 0.00484

\begin{tabular}{|c|c|c|c|c|c|}
\hline Manu & Proc & Prod & WH & DIS & Priority \\
\hline Proc & 1 & 5 & 2 & 3 & 0.48288 \\
\hline Prod & $1 / 5$ & 1 & $1 / 3$ & $1 / 2$ & 0.08815 \\
\hline WH & $1 / 2$ & 2 & 1 & 2 & 0.27197 \\
\hline DIS & $1 / 3$ & 3 & $1 / 2$ & 1 & 0.15699 \\
\hline
\end{tabular}

Table: 3 Goal-2 C.I $=\mathbf{0 . 0 2 0 7 6}$

\begin{tabular}{|c|c|c|c|c|c|}
\hline ISC & IS & CR & CL & PR & Priority \\
\hline IS & 1 & 3 & 6 & 8 & 0.58677 \\
\hline CR & $1 / 3$ & 1 & 3 & 6 & 0.263344 \\
\hline CL & $1 / 6$ & $1 / 3$ & 1 & 2 & 0.09583 \\
\hline PR & $1 / 8$ & $1 / 6$ & $1 / 2$ & 1 & 0.05393 \\
\hline
\end{tabular}

Table: .4 Goal-3 C.I $=\mathbf{0 . 0 0 1 8 4 7}$

\begin{tabular}{|c|c|c|c|c|}
\hline ESC & SQ & SM & B/MT & Priority \\
\hline SQ & 1 & 5 & 7 & 0.64832 \\
\hline SM & $1 / 5$ & 1 & 4 & 0.22951 \\
\hline B/MT & $1 / 7$ & $1 / 4$ & 1 & 0.12202 \\
\hline
\end{tabular}

Table: 5 Goal-4 C.I $=\mathbf{0 . 0 6 1 8 5 6}$

\begin{tabular}{|c|c|c|c|c|}
\hline ESC & SQ & SM & B/MT & Priority \\
\hline SQ & 1 & 5 & 7 & 0.72229 \\
\hline SM & $1 / 5$ & 1 & 4 & 0.20498 \\
\hline B/MT & $1 / 7$ & $1 / 4$ & 1 & 0.07271 \\
\hline
\end{tabular}

Table: .6 Goal-5 C.I $=0.04480$

\begin{tabular}{|c|c|c|c|c|c|}
\hline SDM & CS & IC & I/E & PL & Priority \\
\hline CS & 1 & 3 & 6 & 8 & 0.61658 \\
\hline IC & $1 / 3$ & 1 & 3 & 6 & 0.21100 \\
\hline I/E & $1 / 6$ & $1 / 3$ & 1 & 2 & 0.11826 \\
\hline PL & $1 / 8$ & $1 / 6$ & $1 / 2$ & 1 & 0.05414 \\
\hline
\end{tabular}

Table: 7 Goal-6 C.I $=0.04480$

\begin{tabular}{|c|c|c|c|c|c|}
\hline Int.C & CR & If.Int & I.O.I & RL & Priority \\
\hline CR & 1 & 3 & 5 & 7 & 0.56658 \\
\hline If.nt & $1 / 3$ & 1 & 2 & 6 & 0.24403 \\
\hline I.O.I & $1 / 5$ & $1 / 2$ & 1 & 4 & 0.13882 \\
\hline RL & $1 / 7$ & $1 / 6$ & $1 / 4$ & 1 & 0.04990 \\
\hline
\end{tabular}

Table: 8 Goal-7 C.I $=0.06023$

\begin{tabular}{|c|c|c|c|c|c|c|}
\hline ITS & $\begin{array}{c}\mathrm{CD} \\
\mathrm{R}\end{array}$ & $\begin{array}{c}\mathrm{I} \\
\mathrm{Q}\end{array}$ & $\begin{array}{c}\mathrm{D} \\
\mathrm{E}\end{array}$ & $\begin{array}{c}\mathrm{CE} \\
\mathrm{T}\end{array}$ & $\begin{array}{c}\mathrm{E} \\
\mathrm{T}\end{array}$ & $\begin{array}{c}\text { Priori } \\
\text { ty }\end{array}$ \\
\hline $\begin{array}{c}\mathrm{CD} \\
\mathrm{R}\end{array}$ & 1 & 3 & 5 & 7 & 8 & $\begin{array}{c}0.512 \\
38\end{array}$ \\
\hline $\mathrm{IQ}$ & $1 / 3$ & 1 & 3 & 4 & 6 & $\begin{array}{c}0.245 \\
51\end{array}$ \\
\hline $\mathrm{DE}$ & $1 / 5$ & $1 /$ & 1 & 3 & 6 & $\begin{array}{c}0.139 \\
81\end{array}$ \\
\hline $\mathrm{CE}$ & $1 / 7$ & $1 / 4$ & $1 /$ & 1 & 2 & $\begin{array}{c}0.060 \\
67\end{array}$ \\
$\mathrm{~T}$ & & & 3 & & & $1 / 2$ \\
$\mathrm{ET}$ & $1 / 8$ & $1 /$ & $\begin{array}{c}1 / \\
6\end{array}$ & & 1 & $\begin{array}{c}1 / 037 \\
55\end{array}$ \\
\hline
\end{tabular}

Table: 9 Goal-8 C.I $=0.03579$

\begin{tabular}{|c|c|c|c|c|c|}
\hline VL & Prt/PL & Pac & TM & L & Priority \\
\hline Prt/PL & 1 & 5 & 3 & 2 & 0.47977 \\
\hline Pac & $1 / 5$ & 1 & $1 / 3$ & $1 / 2$ & 0.09043 \\
\hline TM & $1 / 3$ & $1 / 3$ & 1 & $1 / 2$ & 0.17910 \\
\hline L & $1 / 2$ & 2 & 2 & 1 & 0.25068 \\
\hline
\end{tabular}

Published By:

Blue Eyes Intelligence Engineering \& Sciences Publication (C) Copyright: All rights reserved. 